\title{
- IECLASPFED
}

\section{GENERAL ELETRIC}

HANFORD ATOMIC PRODUCTS OPERATION - RICHLAND, WASHINGTON

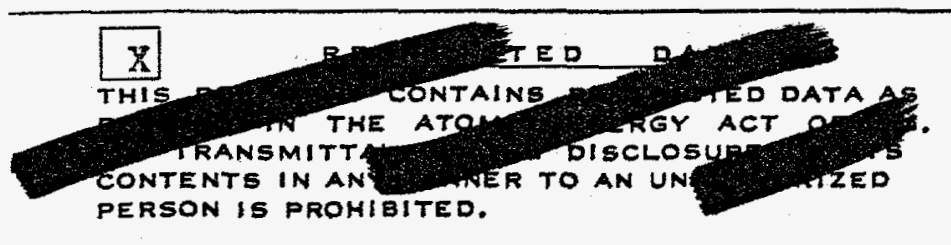

OTHER OFFICIAL CLASEIFIEO INFORMATION

THIS MATERIAL CONTAINS INFORMATION AFFECTING

THE NATIONAL DEFENSE OF THE UNITED STATES

WITHIN THE MEANING OF THE ESPIONAGE LAWS.

TITLE

SPEED-OF-CONTROL LIMITS FOR E REACTOR

TITLE $18, U .5 . C$, SECS, 793 AND 794, THE TRANSMISSION OR REVELATION OF WHICH IN ANY MANNER TO AN UNAUTHORIZED PERSON IS PROHISITED BY LAW.

THIS DOCUMENT MUST S SE LEFT UNATTENDED OR WHEROPU UNAUTHORIZED PERSON TO IT. WHEN NOTA TT MUST BE STORED IN

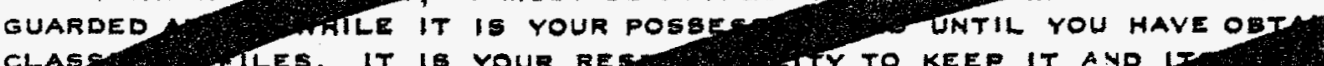

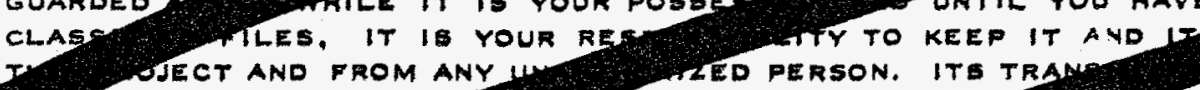

J. P. HAMRIC

RESIDENCE IS PROHLP TE NOT TO BE DUPH OBTAIN THEM FROM HATED ISSUING FILE. TO SIGN IN THE SPACE PROVIDED BELOW.

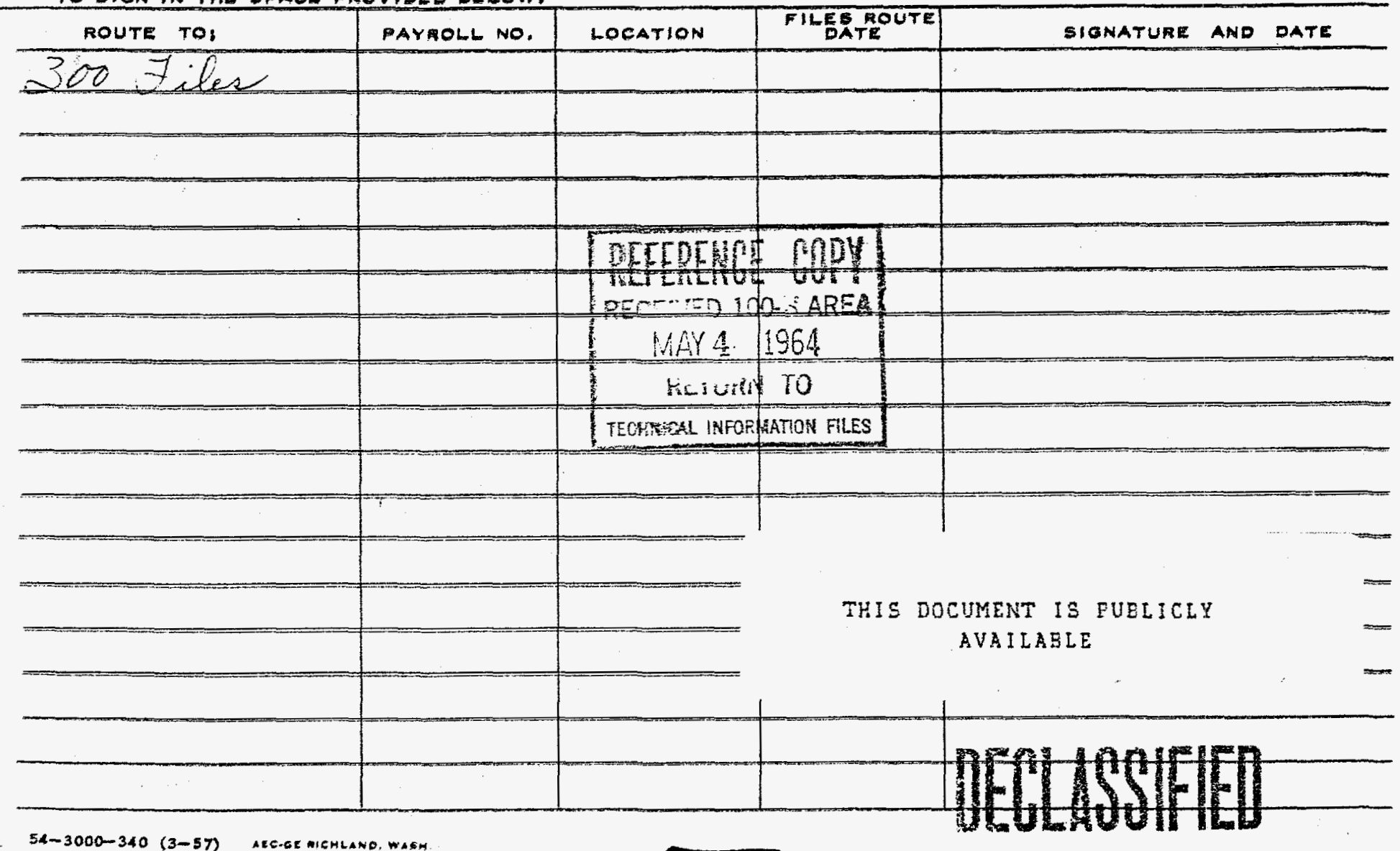

DISTRIBUTION OF THIS DOCUMENT IS UNLIMUAEAS:SIFICATION) pwis 


\section{DISCLAIMER}

Portions of this document may be illegible in electronic image products. Images are produced from the best available original document. 


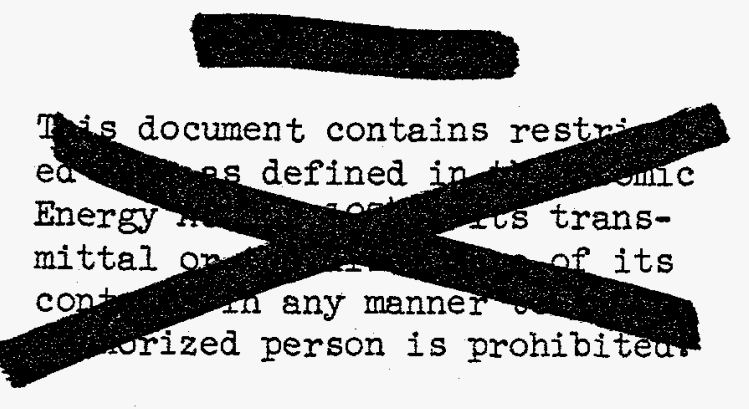

This document classified by:
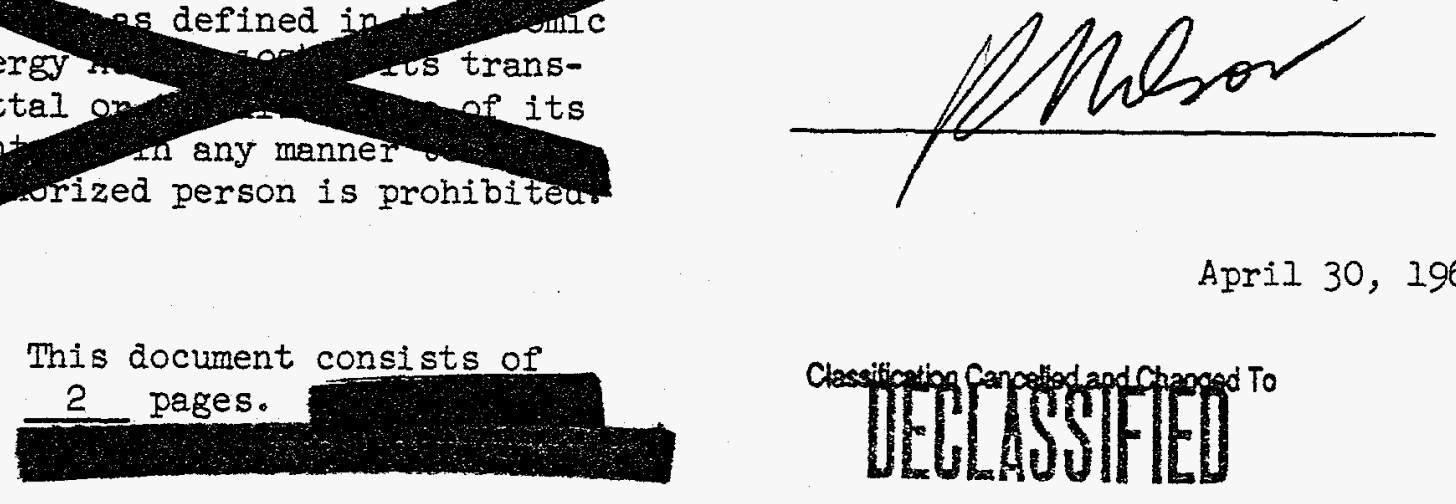

April 30, 1964

R. W. Reid, Manager

Process Technology

1704-D, 100-D Area

\section{SPEED-OF-CONTROL LIMITS FOR H REACTOR}

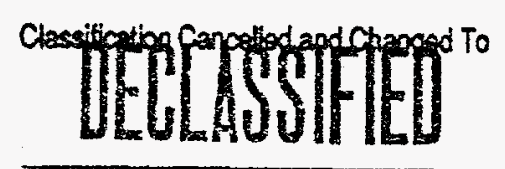

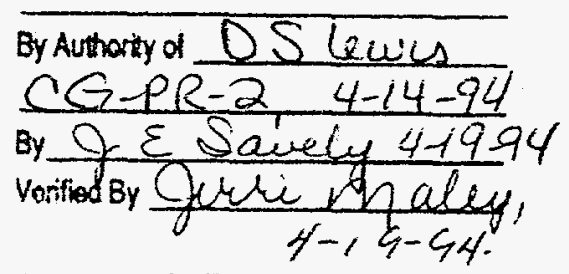

Refs: I) HW-63157, "Parametric Analysis of Hanford Speed-ofControl Criterion," R. Nilson, R. E. Tiller, and J. C. Peden, July, 1961 .

2) HW-55500 RD, "Technical Bases for Standards," Staff of Process and Reactor Development Sub-Section, April 1, 1960 .

Due to the irregular flux pattern in the top portion following the April 19 startup of $\mathrm{H}$ Reactor, speed-of-control limits were evaluated to include the effects of the accompanying decreased worth of the vertical safety rod system.

The worth of the VSR system for the skewed flux condition was calculated to be 60 per cent of the normal strength. For the calculations, the skewed flux condition was assumed uniform from the top of the reactor to the botton, which is conservative. Prior work in this field (Reference 1) shows that such a reduction in the VSR system worth imposes at most a 20 per cent compensating reduction in permitted power level for a given reactivity gain upon water loss.

For the record, there would have been no reduction in equilibrium power (Administrative Limit) necessary up to an exposire of $400 \mathrm{Mwd} / \mathrm{t}$ for speed-of-control requirements. Limits which should have been followed for startup are shown in the table below. It is our understanding that the startup limits were not exceeded.

\section{MASTER}

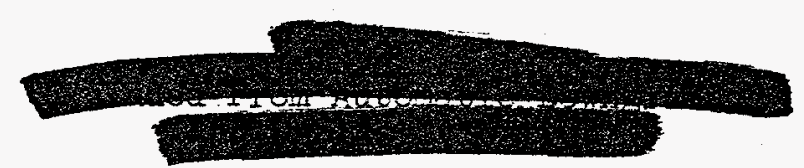


R. W. Reid

Graphite Temperature, Flux-Squared Weighted

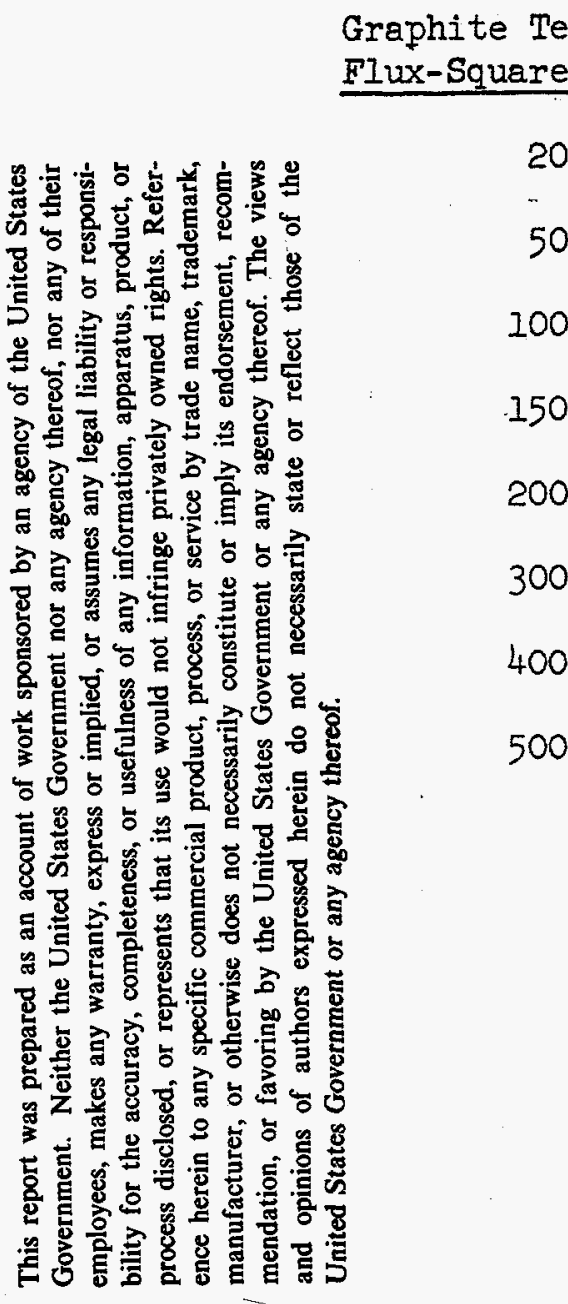

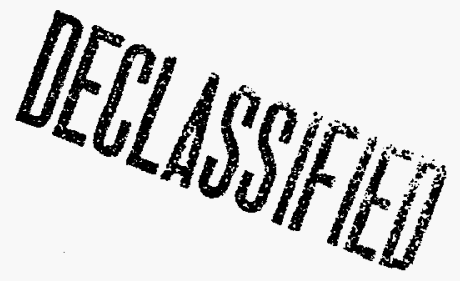

HW-82067

Apriz 30, 1964

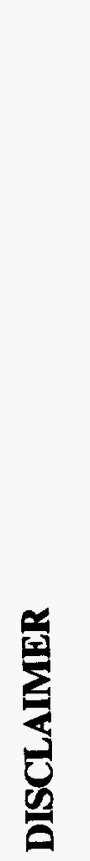

JP Hamric:eck

\section{Distribution}

1. TW Ambrose

2. CE Bowers

3. GC Fulimer

4. $\mathrm{OH}$ Greager

5. JP Hamric

6. AK Hardin

7. R Nilson

8. RW Reid

$2 \Rightarrow 000$ Files.

10. Record Center
Power Ievel, o of Administrative Limit

34.9

$38 \cdot 3$

46.9

61.2

71.8

96.6

100.0

100.0

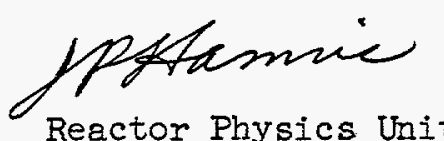

Reactor Physics Unit

Process and Reactor Development SS

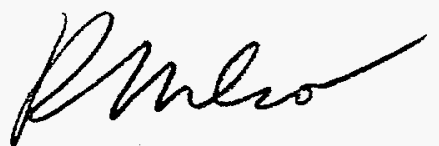

Approved: R. Nilson, Supervisor Reactor Physics Unit

Process and Reactor Development SS

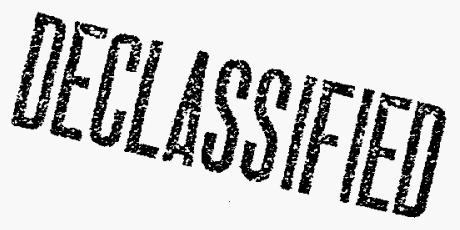

